\title{
Effects of Mental Disorders on the Emotional Intelligence Levels of Brazilian Medical Students: a Single Center Cross-Sectional Study, 2017-2018
}

\author{
Efeitos da Doença Mental sobre os Níveis de Inteligência \\ Emocional em Estudantes de Medicina Brasileiros: Estudo \\ Transversal Unicêntrico, 2017-2018
}

\author{
Marayra Inês França Coury ${ }^{I}$ [D \\ João Gabriel Menezes Duca II \\ Antonio Toledo Júnior ${ }^{I I} \mathbb{D}$
}

\section{KEYWORDS}

- Emotional Intelligence.

- Mental Health.

- Medical Education.

- Medicine.

Introduction: Recent studies have shown the direct effects of emotional intelligence (EI) on medical practice and, more specifically, on establishing and maintaining a good doctor-patient relationship. The aim was to compare the EI levels of students from different years of medical school and to evaluate other factors that affect EI levels. Method: This was a cross-sectional study of medical students attending the $1^{\text {st }}, 3^{\text {rd }}$ and $6^{\text {th }}$ years in a private institution in Belo Horizonte, Minas Gerais, Brazil. A non-probabilistic convenience sample was used. EI levels were evaluated using the Schutte Self-Report EI Test, and demographic and personal data were collected. All volunteers signed the free and informed consent form prior to study inclusion. Statistical analysis used ANOVA, Student's t-test, Pearson correlation and linear regression. A significance level of 0.05 was adopted. Results: Two hundred twenty-five volunteers were recruited between October/2017 and April/2018. Sixteen (7.1\%) were excluded due to incomplete questionnaires. The final sample comprised 209 participants ( 71 from the $1^{\text {st }}$ year, 69 from the $3^{\text {rd }}$ year and 69 from the $6^{\text {th }}$ year). Most were women (66.0\%), 95.2\% were single, $10.0 \%$ had previously graduated and $16.3 \%$ reported a previous mental disorder diagnosis. The mean age was $23.2( \pm 3.9)$ years. There was no difference in the EI overall score and in the different EI domains scores among the students from the three years. Pearson's test showed a weak positive correlation between age and total score $(r=0.172 ; p=0.013)$ and perception of emotion $(r=0.236 ; p=0.001)$. Multiple regression showed a significant positive association between age and the total score $(p=0.040)$, Perception of Emotion $\left(p_{\text {adjusted }}=0.013\right)$ and Managing Others' Emotions ( $\left.p_{\text {adjusted }}=0.020\right)$. A significant reduction in the total score ( $\left.p_{\text {adjusted }}=0.033\right)$, in Managing Own Emotions $\left(p_{\text {adjusted }}<0.001\right)$ and in the Managing Others' Emotions $\left(p_{\text {adjusted }}=0.025\right)$ was found for volunteers who reported a previous mental disorder. Conclusion: High levels of EI were observed in the 3 years. No association was observed between different EI scores and the course year. There was a positive correlation between age and total EI score, Perception of Emotions, Managing Own Emotions and Managing Others' Emotions. The presence of a mental disorder was associated with a reduction in the total score and the scores for Managing Own Emotions and Managing Others' Emotions.

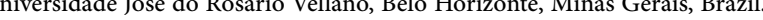




\section{PALAVRAS-CHAVE}

- Inteligência emocional.

- Saúde Mental.

- Educação Médica.

- Medicina.

\section{RESUMO}

Introdução: Estudos recentes mostram os efeitos diretos da inteligência emocional (IE) na prática médica e, mais especificamente, no estabelecimento e na manutenção de boa relação médico-paciente. Os objetivos deste estudo foram comparar os níveis de IE entre estudantes de diferentes anos de um curso de Medicina e avaliar fatores que influenciam esses níveis. Método: Trata-se de estudo transversal com estudantes de Medicina do primeiro, terceiro e sexto anos de uma instituição privada em Belo Horizonte, Minas gerais, Brasil. Os níveis de IE foram medidos por meio de teste autoaplicado de inteligência emocional de Schutte. Coletou-se também dados pessoais e demográficos. Todos os voluntários assinaram o Termo de Consentimento Livre e Esclarecido antes de sua inclusão no estudo. O teste t de Student, a ANOVA, o teste de correlação de Pearson e a regressão linear foram utilizados na análise estatística. Resultados: Foram recrutados 255 voluntários entre outubro de 2017 e abril de 2018. Dezesseis (7,1\%) alunos foram excluídos porque os questionários estavam incompletos. A amostra final foi composta de 209 participantes (71 do primeiro ano, 69 do terceiro ano e 69 do sexto ano). A maioria era do sexo feminino (66,0\%), 95,2\% eram solteiros, 10,0\% tinham graduação prévia e 16,3\% relataram diagnóstico prévio de distúrbio mental. A idade média foi de $23,2( \pm 3,9)$ anos. Não houve diferença entre os escores total de IE e de seus diferentes domínios entre os 3 anos. O teste de Pearson mostrou correlação positiva fraca entre a idade e o escore total $(r=0,172 ; p=0,013)$ e a "percepção das emoções" $(r=0,236 ; p=0,001)$. A análise multivariada mostrou associação positiva significativa entre a idade e o escore total $\left(p_{\text {ajustado }}=0,040\right)$, a "percepção das emoções" ( $\left.p_{\text {ajustado }}=0,013\right)$ e o "gerenciamento das emoções dos outros" $\left(p_{\text {ajustado }}=0,020\right)$. Redução significativa do escore total ( $\left.p_{\text {ajustado }}=0,033\right)$, do "gerenciamento das próprias emoções" $\left(p_{\text {ajustado }}<0,001\right)$ e do "gerenciamento das emoções dos outros" $\left(p_{\text {ajustado }}=0,025\right)$ foi observada entre os voluntários que relataram distúrbio mental prévio. Conclusões: Níveis elevados de IE foram observados nos 3 anos. Houve correlação positiva entre a idade e o escore total, a "percepção das emoções", o "gerenciamento das próprias emoções" e o "gerenciamento das emoções dos outros". A presença de distúrbio mental foi associada à redução do escore total, do "gerenciamento das próprias emoções" e do "gerenciamento das emoções dos outros".

Received on $5 / 7 / 20$

Accepted on 5/11/20

\section{INTRODUCTION}

Emotional intelligence (EI) is a much-debated topic, not only in medicine and healthcare. It can be defined as the ability to accurately perceive, evaluate and express emotions; the ability to perceive and/or generate feelings when they facilitate thought; the ability to understand emotion and emotional knowledge; and the ability to control emotions to promote emotional and intellectual growth ${ }^{1}$. It is a social skill and can be taught, trained or improved ${ }^{2}$.

Several studies have shown the direct effects of EI on medical practice and, more specifically, on establishing and maintaining a good doctorpatient relationship ${ }^{3}$. Canales and Cleveland discussed the importance of a medical professional's ability to understand and manage emotions, feelings and behaviors. Their analysis revealed that this skill is developed automatically during ongoing work with and care of patients. Nonetheless, they concluded that curricular changes in medical schools would provide doctors-in-training with greater aptitude in relation to skills involving $\mathrm{EI}^{4}$.

Hernandez-Vargas and Dickinson-Bannack claimed that EI is an essential skill in medical practice ${ }^{5}$. It assists the doctor-patient relationship, positively affects quality of care and patient satisfaction, improves doctor performance, level of involvement and job satisfaction and facilitates the development of communication skills ${ }^{3,5}$.

In a literature review, Johnson established that the ability to evaluate a patient's emotions improved information collection and diagnostic accuracy. The author highlighted that strategies to train, develop, test and evaluate medical students' emotional skills must be addressed in a longitudinal and comprehensive way throughout medical school. The goal is not just to establish but also to facilitate the incorporation of these concepts and skills ${ }^{6}$.

Another recent study that evaluated the effect of EI on medical students' performance in surgical activities showed that the ability to support and respond well to workplace and occupational stress was linked to students' or doctors' EI levels. The results suggested the need of training the cognitive area, which includes these skills, so students could develop better work-related stress coping mechanisms ${ }^{7}$.

Therefore, improving doctors' and medical students' EI can be considered a possible solution for mitigating the deleterious effects caused by the complexity of a doctor's relationship with the work environment, as well as his/her intrapersonal and interpersonal relationships. This skill can be taught and improved, and the effects of its inclusion in medical school curricula should be systematically evaluated ${ }^{3,5}$.

There are few articles on EI and medical education in Brazil. An instrument to evaluate EI levels ${ }^{8}$ has only recently been validated for Brazilian Portuguese, and our literature review did not identify any studies that have evaluated EI levels in Brazilian medical students. The main objectives of this study were therefore to compare the EI levels of students from different years of medical school and to identify factors that affected these levels.

\section{MATERIALS AND METHODS}

Study design and population

This was a cross-sectional study that evaluated students in the $1^{\text {st }}$, $3^{\text {rd }}$ and $6^{\text {th }}$ years of a private medical school at the Universidade José do 
Rosário Vellano (UINFENAS), Belo Horizonte Campus, in the years 2017 and 2018. The University has its own admission process. In Brazil, the medical program structure is different from that in the United States and other European countries, as the preclinical and clinical years comprise a single program with a total length of 6 year.

The sample size was calculated as 177 volunteers, 59 from each year, according to StatCalc EpiInfo (CDC, USA) for cross-sectional studies, based on a total population of 450 medical students (150 students from each year), a $25.0 \%$ expected frequency of high EI levels, margin of error of $5 \%$ and a $95 \%$ confidence interval. Considering possible losses and incomplete questionnaires, the sample size was increased by $10 \%$, up to 195 volunteers, 65 from each year of medical school. Recruitment was done by convenience. All students from each of the three years were invited to participate. In all cases, the researchers oversaw questionnaire completion, but without interfering in the process. All volunteers signed the free and informed consent form prior to inclusion in the study.

\section{Procedures}

The main study outcome was the EI level, and secondary outcomes were EI levels within different domains. Outcomes were measured using the version of the Schutte Self-Report EI Test (SSEIT) that has been validated to be used in Brazil ${ }^{8,9}$. The SSEIT is a self-administered questionnaire with 33 items, divided into four domains: Perception of Emotions, Managing Own Emotions, Managing Others' Emotions, and Utilization of Emotions. The items use a Likert scale with five response options: (1) strongly disagree, (2) partially disagree, (3) neither disagree, nor agree, (4) partially agree and (5) strongly agree. When calculating the final score, the response values of items 5, 28 and 33 must be inverted before summing up all response values. The score for each of the four domains is calculated by adding the corresponding items: Perception of Emotion (items 5, 9, 15, 18, 19, 22, 25, 29, 32, 33), Managing Own Emotions (items 2, 3, 10, 12, 14, 21, 23, 28, 31), Managing Others' Emotions (items 1, 4, 11, 13, 16, 24, 26, 30) and Utilization of Emotions (items $6,7,8,17,20,27)$. The total score ranges from 33-165. Higher scores indicate higher levels of EI ${ }^{8,9}$. The main exposure variable was the medical school year, divided into three groups: $1^{\text {st }}, 3^{\text {rd }}$ and $6^{\text {th }}$ years. The following variables were also collected: gender, age, marital status, children (yes/no), religion, previous undergraduate course, participation in extracurricular activities and self-reported previous mental disorder diagnosis. Mental disorder was evaluated through two questions. A yes or no question: "Have you ever had a confirmed diagnosis of depression or other mental disorders (except epilepsy)", and an open one: "What was the diagnosis?". The second question was considered only when the answer to the first one was "yes".

\section{Statistical analysis}

In the descriptive analysis, the mean and standard deviation were used for continuous variables, and frequency distribution was used for categorical variables. ANOVA was used to compare EI scores among school years, and Student's $t$-test was used to compare EI and gender, marital status (single or not), religion, previous undergraduate course, participation in extracurricular activities and previous mental disorder diagnosis. The two-tailed Fisher's exact test was used to compare gender and previous mental disorder diagnosis. Pearson's correlation test was used to evaluate the association between age and EI score. Multiple regression analysis was performed for the total EI score and its domains in relation to the variables with $\mathrm{p}$ values $<0.10$. A significance level of 0.05 was adopted. IBM $^{\star}$ SPSS $^{\star}$ Statistics software v. 19 (IBM, USA) was used for the statistical analysis.

\section{Ethical aspects}

This study was approved by Institutional Ethics Committee (Opinion N. 2.048.558) and is in accordance with the current version of the Declaration of Helsinki and Resolution 466/2012 of CONEP and its updates. All volunteers received clarification on the study objectives and signed the free and informed consent form before inclusion.

\section{RESULTS}

Between October 2017 and April 2018, 225 volunteers were recruited. Of these, 16 (7.1\%) were excluded due to incomplete questionnaires. The final sample comprised 209 participants, 71 from the $1^{\text {st }}$ year, 69 from the $3^{\text {rd }}$ year and 69 from the $6^{\text {th }}$ year of medical school.

Table 1 shows the demographic and personal characteristics of the 209 volunteers according to the course year. A predominance of females (138 - 66.0\%) and single individuals (199 - 95.2\%) was observed. Only four volunteers (1.9\%) had children, and 19 (9.1\%) declared having no religion. Twenty-one (10.0\%) had previous degrees, and $128(61.2 \%)$ reported participating in extracurricular activities. The frequency of previous depression or another mental disorder diagnosis was $16.3 \%$ (34 volunteers). The mean overall age was $23.2( \pm 3.9)$ years.

Of the 21 participants with a previous degree, 17 (85.0\%) had graduated in the health area, with the most frequent degree being nursing (7 - 35.0\%), followed by physiotherapy and pharmacy, both with three participants (15.0\%) each. Some of the 34 volunteers with previous mental disorders reported more than one diagnosis, totaling 41 diagnoses. The most frequent ones were depression $(21-51.2 \%)$ and anxiety-related disorders (18 - 44.0\%).

Table 2 shows EI total score and its domains according to the medical course year. None of these differences were statistically significant. All scores could be considered high, as they reach at least $75.0 \%$ of the maximum score.

Table 3 shows the variables with a statistically significant difference regarding total EI score and its domains, except for age. There were no significant differences between EI score and having a religion or participating in extracurricular activities. Men had a statistically higher score than women for the Managing Own Emotions domain, $38.0 \pm 4.3$ versus $36.3 \pm 4.6(\mathrm{p}=0.013)$, respectively. Students with a previous degree also showed higher scores in the Perception of Emotion domain, $39.5 \pm$ 4.7 versus $36.7 \pm 5.4(\mathrm{p}=0.021)$, respectively. Volunteers who reported a previous mental disorder had a lower total EI score (124.6 \pm 13.2 versus $129.7 \pm 13.0, \mathrm{p}=0.036)$ and a lower score in the Managing Own Emotions domain $(33.7 \pm 4.1$ versus $37.5 \pm 5.5, \mathrm{p}<0.001)$.

Pearson's correlation showed a weak but statistically significant positive association between age, total EI score and Perception of Emotion domain (Figure 1). The other domains were not statistically significant.

Considering that the volunteers with a previous degree were older than those without one $(30.8 \pm 5.1$ years versus $22.3 \pm 2.8$ years; $\mathrm{p}<0.001)$ and that the reporting of a previous mental disorder was significantly higher

REVISTA BRASILEIRA DE EDUCAÇ̃̃o MÉDICA

3 44(3) : e088; 2020 
among women than among men $(21.1 \%$ versus $5.6 \% ; \mathrm{p}=0.003, \mathrm{RR}=1.43$ - 95\% CI 1.21 - 1.70), it was decided to include these four variables in the multiple regression analysis, regardless of their crude $\mathrm{p}$ value. According to Table 4, it was observed that age increase positively affected the total score $\left(\mathrm{p}_{\text {adjusted }}=0.040\right)$, Perception of Emotion $\left(\mathrm{p}_{\text {adjusted }}=0.013\right)$ and Managing
Others' Emotions $\left(\mathrm{p}_{\text {adjusted }}=0.020\right)$. Self-report of a previous mental disorder negatively affected the total EI score $\left(\mathrm{p}_{\text {adjusted }}=0.033\right)$ and the scores for Managing Own Emotions ( $\mathrm{p}_{\text {adjusted }}=<0.001$ ) and Managing Others' Emotions $\left(\mathrm{p}_{\text {adjusted }}=0.025\right)$. The multiple regression analysis revealed no association between gender, previous degree and EI levels.

\begin{tabular}{|c|c|c|c|c|c|c|c|c|c|}
\hline \multirow{2}{*}{ Variable } & & \multicolumn{2}{|c|}{$1^{\text {st }}$ year } & \multicolumn{2}{|c|}{$3^{\text {rd }}$ year } & \multicolumn{2}{|c|}{$6^{\text {th }}$ year } & \multicolumn{2}{|c|}{ Total } \\
\hline & & $\mathbf{N}$ & $\%$ & $\mathbf{n}$ & $\%$ & $\mathbf{n}$ & $\%$ & $\mathbf{n}$ & $\%$ \\
\hline \multirow{2}{*}{ Gender } & Female & 46 & 64.8 & 45 & 65.2 & 47 & 68.1 & 138 & 66.0 \\
\hline & Male & 25 & 35.2 & 24 & 34.8 & 22 & 31.9 & 71 & 34.0 \\
\hline \multirow{3}{*}{ Marital status } & Single & 67 & 94.4 & 66 & 95.7 & 66 & 95.7 & 199 & 95.2 \\
\hline & Married & 4 & 5.6 & 2 & 2.9 & 2 & 2.9 & 8 & 3.8 \\
\hline & Other & 0 & 0.0 & 1 & 1.4 & 1 & 1.4 & 2 & 1.0 \\
\hline \multirow{2}{*}{ Children } & Yes & 1 & 1.4 & 2 & 2.9 & 1 & 1.4 & 4 & 1.9 \\
\hline & No & 69 & 98.6 & 67 & 97.1 & 68 & 98.6 & 204 & 98.1 \\
\hline \multirow{2}{*}{ Religion } & Yes & 64 & 90.1 & 62 & 89.9 & 64 & 92.8 & 190 & 90.9 \\
\hline & No & 7 & 9.9 & 7 & 10.1 & 5 & 7.2 & 19 & 9.1 \\
\hline \multirow{2}{*}{ Previous degree } & Yes & 6 & 8.5 & 6 & 8.7 & 9 & 13.0 & 21 & 10.0 \\
\hline & No & 65 & 91.5 & 63 & 91.3 & 60 & 87.0 & 188 & 90.0 \\
\hline \multirow{2}{*}{$\begin{array}{c}\text { Extracurricular } \\
\text { activities }\end{array}$} & Yes & 17 & 23.9 & 62 & 89.9 & 49 & 71.0 & 128 & 61.2 \\
\hline & No & 54 & 76.1 & 7 & 10.1 & 20 & 29.0 & 81 & 38.8 \\
\hline \multirow{2}{*}{$\begin{array}{c}\text { Previous mental } \\
\text { disorder }\end{array}$} & Yes & 13 & 18.3 & 8 & 11.6 & 13 & 18.8 & 34 & 16.3 \\
\hline & No & 58 & 81.7 & 61 & 88.4 & 56 & 81.2 & 175 & 83.7 \\
\hline Age & Mean (SD) & \multicolumn{2}{|c|}{$21.0(3.76)$} & \multicolumn{2}{|c|}{$23.0(3.21)$} & \multicolumn{2}{|c|}{$25.8(3.11)$} & \multicolumn{2}{|c|}{$23.2(3.90)$} \\
\hline
\end{tabular}

SD - standard deviation

Source: prepared by the authors

Table 2

Total emotional intelligence score and its domains scores for 209 volunteers according to the medical course year

\begin{tabular}{|c|c|c|c|c|c|c|c|c|c|}
\hline \multirow{2}{*}{ Variable } & \multicolumn{2}{|c|}{$1^{\text {st }}$ year } & \multicolumn{2}{|c|}{$3^{\text {rd }}$ year } & \multicolumn{2}{|c|}{$6^{\text {th }}$ year } & \multicolumn{2}{|c|}{ Total } & \multirow{2}{*}{$\mathbf{p}^{*}$} \\
\hline & Mean & SD & Mean & SD & Mean & SD & Mean & SD & \\
\hline Total score & 127.9 & 13.7 & 127.6 & 13.1 & 131.2 & 12.4 & 128.9 & 13.1 & 0.208 \\
\hline Perception of emotion & 36.5 & 5.3 & 36.3 & 5.3 & 38.0 & 5.4 & 36.9 & 5.4 & 0.115 \\
\hline Managing Own Emotions & 36.3 & 5.3 & 36.7 & 4.0 & 37.6 & 4.1 & 36.9 & 4.6 & 0.212 \\
\hline Managing Others' Emotions & 30.5 & 4.1 & 30.7 & 4.3 & 31.6 & 4.0 & 30.9 & 4.1 & 0.223 \\
\hline Utilization of emotions & 24.6 & 3.6 & 23.9 & 3.9 & 23.9 & 3.5 & 24.6 & 3.7 & 0.412 \\
\hline
\end{tabular}

SD - standard deviation; *ANOVA

Source: prepared by the authors 


\section{Table 3}

Total scores for Emotional Intelligence and its domains among 209 volunteers according to gender, previous degree and self-reported previous mental disorder

\begin{tabular}{|c|c|c|c|c|c|}
\hline \multirow{2}{*}{ Gender } & \multicolumn{2}{|c|}{ Female } & \multicolumn{2}{|c|}{ Male } & \multirow{2}{*}{$\mathbf{p}^{*}$} \\
\hline & Mean & SD & Mean & SD & \\
\hline Total score & 128.0 & 12.9 & 130.5 & 13.6 & 0.200 \\
\hline Perception of Emotion & 36.7 & 5.2 & 37.3 & 5.8 & 0.451 \\
\hline Managing Own Emotions & 36.3 & 4.6 & 38.0 & 4.3 & 0.013 \\
\hline Managing Others' Emotions & 31.0 & 4.0 & 30.7 & 4.4 & 0.608 \\
\hline Utilization of Emotions & 24.0 & 3.8 & 24.5 & 3.4 & 0.331 \\
\hline \multirow{2}{*}{ Previous degree } & \multicolumn{2}{|c|}{ No } & \multicolumn{2}{|c|}{ Yes } & \\
\hline & Mean & SD & Mean & SD & $\mathrm{p}$ \\
\hline Total score & 128.4 & 13.3 & 133.1 & 10.5 & 0.120 \\
\hline Perception of Emotion & 36.7 & 5.4 & 39.5 & 4.7 & 0.021 \\
\hline Managing Own Emotions & 36.8 & 4.7 & 37.9 & 3.3 & 0.272 \\
\hline Managing Others' Emotions & 30.9 & 4.2 & 31.0 & 3.9 & 0.929 \\
\hline Utilization of Emotions & 24.1 & 3.7 & 24.7 & 3.2 & 0.457 \\
\hline \multirow{2}{*}{$\begin{array}{l}\text { Self-report of previous } \\
\text { mental disorder }\end{array}$} & \multicolumn{2}{|c|}{ No } & \multicolumn{2}{|c|}{ Yes } & \\
\hline & Mean & SD & Mean & $\mathrm{SD}$ & $\mathrm{P}$ \\
\hline Total score & 129.7 & 13.0 & 124.6 & 13.2 & 0.036 \\
\hline Perception of Emotion & 36.9 & 5.3 & 37.4 & 5.9 & 0.594 \\
\hline Managing Own Emotions & 37.5 & 4.1 & 33.7 & 5.5 & $<0.001$ \\
\hline Managing Others' Emotions & 31.2 & 4.2 & 29.7 & 3.6 & 0.054 \\
\hline Utilization of Emotions & 24.2 & 3.7 & 23.8 & 3.3 & 0.539 \\
\hline
\end{tabular}

SD - standard deviation; ${ }^{*}$ Student's t-test

Source: prepared by the authors

\section{Table 4}

Multiple regression of age, gender, previous graduation, and self-

reported previous mental disorder and emotional intelligence scores

\begin{tabular}{|c|c|c|c|c|}
\hline \multirow{2}{*}{$\begin{array}{l}\text { Variable } \\
\text { Total score }\end{array}$} & \multicolumn{2}{|c|}{$\begin{array}{l}\text { Non-standardized } \\
\text { coefficients }\end{array}$} & \multirow[t]{2}{*}{$\mathbf{p}_{\text {crude }}$} & \multirow[t]{2}{*}{$\mathbf{p}_{\text {adjusted }}$} \\
\hline & beta & standard error & & \\
\hline Age & 0.626 & 0.302 & 0.013 & 0.040 \\
\hline Gender & 1.595 & 1.921 & 0.200 & 0.407 \\
\hline Previous degree & -0.069 & 3.912 & 0.120 & 0.986 \\
\hline Previous mental disorder & -5.306 & 2.472 & 0.036 & 0.033 \\
\hline Perception of Emotion & beta & standard error & $\mathrm{p}_{\text {crude }}$ & $\mathrm{p}_{\text {adjusted }}$ \\
\hline Age & 0.311 & 0.124 & 0.001 & 0.013 \\
\hline Gender & 0.660 & 0.784 & 0.451 & 0.401 \\
\hline Previous degree & 0.200 & 1.598 & 0.021 & 0.901 \\
\hline Previous mental disorder & 0.411 & 1.009 & 0.594 & 0.684 \\
\hline Managing Own Emotions & beta & standard error & $\mathrm{p}_{\text {crude }}$ & $\mathrm{p}_{\text {adjusted }}$ \\
\hline Age & 0.177 & 0.101 & 0.068 & 0.082 \\
\hline Gender & 1.063 & 0.642 & 0.013 & 0.099 \\
\hline Previous degree & 0.029 & 1.308 & 0.272 & 0.983 \\
\hline Previous mental disorder & -3.658 & 0.826 & $<0.001$ & $<0.001$ \\
\hline Managing Others' Emotions & beta & standard error & $\mathrm{p}_{\text {crude }}$ & $\mathrm{P}_{\text {adjusted }}$ \\
\hline Age & 0.225 & 0.096 & 0.092 & 0.020 \\
\hline Gender & -0.640 & 0.609 & 0.608 & 0.295 \\
\hline Previous degree & -1.708 & 1.241 & 0.929 & 0.170 \\
\hline Previous mental disorder & -1.773 & 0.784 & 0.054 & 0.025 \\
\hline Utilization of emotions & beta & standard error & $\mathrm{p}_{\text {crude }}$ & $\mathrm{p}_{\text {adjusted }}$ \\
\hline Age & -0.086 & 0.087 & 0.795 & 0.322 \\
\hline Gender & 0.511 & 0.550 & 0.331 & 0.354 \\
\hline Previous degree & 1.411 & 1.119 & 0.457 & 0.209 \\
\hline Previous mental disorder & -0.286 & 0.707 & 0.539 & 0.686 \\
\hline
\end{tabular}

Source: prepared by the authors

\section{Figure 1}

Scatter plot of age and Emotional Intelligence scores
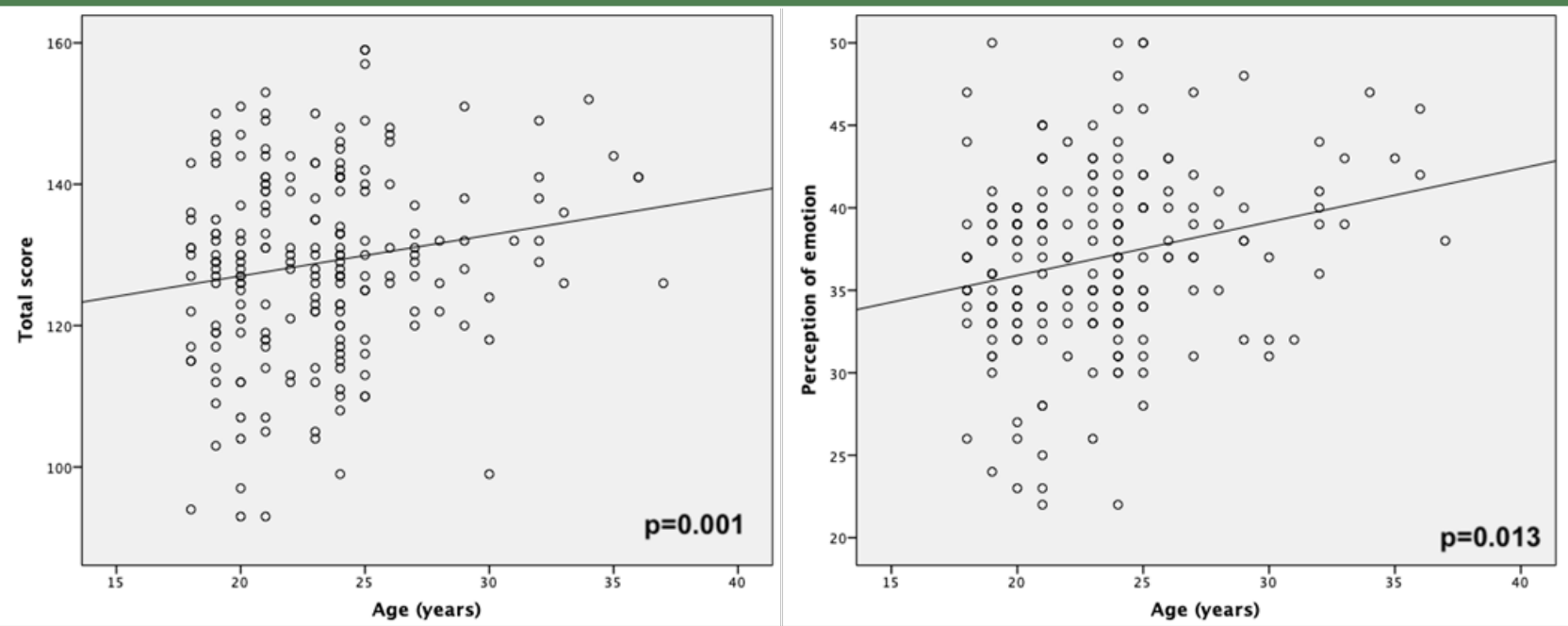

Source: prepared by the authors 


\section{DISCUSSION}

The objectives of this study were to compare the EI levels among students at three different years of medical school and to evaluate the factors associated with EI. Overall, there was no difference in total EI score, nor in its domain scores among the three groups. The observed scores were high, with $6^{\text {th }}$ year students having slightly higher values than the other two groups, but with no significant difference. The $1^{\text {st }}$ year students' scores were higher than expected, suggesting that the sample was possibly underestimated and did not have sufficient statistical power to indicate whether there were really any differences between the groups. The initial analysis showed differences between EI levels and a previous degree, gender and self-reported mental disorders. There was also a positive weak correlation, but statistically significant, between age and EI.

The results of this study suggest that a previous degree might be associated with higher levels of EI, especially with regard to the Perception of Emotion domain. However, age could be a confounding factor in this association, as the students with a previous degree were older than those who were working toward their first degree $(30.8 \pm 5.1$ years versus $22.3 \pm 2.8$ years; $\mathrm{p}<0.001$ ). The multivariate analysis showed that in the population studied, the true association was found between EI levels and age, rather than a previous degree. Several studies support this association. Fariselli, Ghini and Freedman showed that for most people, EI levels improve over time and through life experience ${ }^{10}$. More specifically, regarding age, Cabello et al. found an inverted " $U$ " pattern in the association between age and EI levels measured by two different tests, demonstrating that younger ( $<31$ years) and older volunteers (> 45 years) can have lower EI levels than adults of middle age (32 to 44 years $)^{11}$. In a study conducted in 2017 , Sharma observed similar findings, which indicated that total EI score increases with age but that skill and sensitivity are greater between 24 and 34 years of age ${ }^{12}$. Further exploring this association with age, Atkins and Stough observed that the ability to use emotions to solve problems increases with age, while the ability to control strong emotions can decrease with age ${ }^{13}$.

The bivariate analysis revealed an association between gender and EI; however, this association was ruled out by the multivariate analysis. Nevertheless, it is important to discuss the association between gender and EI, as the initial results of this study indicated that men had higher scores than women in the Managing Own Emotions domain (38.0 \pm 4.3 versus $36.3 \pm 4.6 ; \mathrm{p}=0.013)$. This finding is contrary to that in the literature, which shows that higher EI levels are usually observed in women $^{14-16}$. The effect of gender on EI levels has been the subject of intense discussion in recent years, as different studies support the hypothesis that women have a tendency to have higher EI levels than men, while others refute this hypothesis, demonstrating that this association may be due to methodological bias ${ }^{17-20}$.

In a study that evaluated 177 medical students, Carr observed higher EI levels (total score and its domains) in $\mathrm{men}^{21}$. In a cross-sectional study also carried out with medical students from different years, Vasefi, Dehghani and Mirzaaghapoor found no statistically significant difference in scores between genders. The authors suggest that even if women really have higher EI levels, they would be more susceptible to greater "emotional exhaustion" from everyday life difficulties, which would lead to a decrease in EI assessment test scores and a consequent reduction in significance when the two genders' scores are compared ${ }^{22}$.
A possible explanation for the lack of an association between gender and EI in this study is the higher frequency of previous mental disorders in women ( $21.7 \%$ versus $5.6 \% ; \mathrm{p}=0.003)$, as mental disorders are known to have a negative effect on EI and its domains ${ }^{23-28}$.

Although the frequency of previous mental disorders observed in the study is almost half the frequency of recent reports in the international and national literature, at $16.3 \%$ compared to $27.2 \%^{29}$ and $31.4 \%^{30}$, respectively, the multivariate analysis showed a negative association between reported mental disorders and total EI score $(\mathrm{p}=0.033)$, as well as lower scores for the Managing Own Emotions $(\mathrm{p}<0.001)$ and Managing Others' Emotions ( $\mathrm{p}=0.025)$ domains.

Hertel, Schütz and Lammers concluded that individuals with major depressive, borderline personality and substance abuse disorders have significant deficits in EI assessment test scores when compared to those without mental disorders ${ }^{25}$. In addition, the authors also indicated that this difference was even more significant when evaluating skills involved in the Perception of others' emotions and Managing own emotions ${ }^{25}$. Moreover, Downey et al. concluded that EI levels measured by testing may be predictive of the early identification of individuals at risk for major depression ${ }^{31}$.

Fernandez-Berrocal, Alcaide and Extremera also demonstrated that anxiety and depression negatively correlate to EI levels ${ }^{32}$. In addition, this study also found that the ability to discriminate feelings and manage own emotions are skills associated with better psychological adjustment, regardless of the effects of self-esteem and thought suppression on these test scores ${ }^{32}$. Holt and Jones describe how the inability to regulate anxiety can affect an individual's performance on EI evaluation tests and that would lead to lower scores on these tests due to these individuals' greater distraction from the tasks in which they are involved ${ }^{33}$.

In addition to depression and anxiety, other mental and behavioral disorders are strongly correlated to lower EI levels. Khoshakhlagh and Faramarzi reported a statistically significant association between EI, mental disorders and internet addiction. They concluded that mental disorders such as anxiety, obsessive-compulsive disorder, aggression, phobias and hypochondria are good predictors of internet addiction and are closely related to lower EI levels when they are measured in tests ${ }^{34}$. These reports support this study's observations.

One limitation of this study is inherent to the instrument used for EI level assessment. Self-report instruments have a tendency to overestimate EI levels, as respondents may offer the response that they consider socially acceptable, rather than an honest evaluation of their situation ${ }^{35-38}$. The alternative to this would be the use of performance instruments, requiring the individual observation of volunteers in a real or simulated environment, which is operationally infeasible for large-scale studies ${ }^{38,39}$. Despite the possibility of an overestimation of scores, the values observed in this study are similar to those in other studies of university students in other countries ${ }^{8,35,40-47}$. Another limitation is related to the cross-sectional design, which evaluated different groups of people in different years of the course. The ideal design to evaluate the variation in EI levels over the course would be a cohort. However, this would entail a long, expensive and operationally complex study, as participants would have to be followed for at least 6 years. Other limitations are the fact that it is a single-center study and the absence of the assessment of specific mental disorders.

Despite these limitations, to the best of our knowledge, this is the first study to evaluate EI levels among medical students in Brazil and one 
of the very few in international literature that correlated mental disorders with low EI levels among medical students, which makes it unique. Moreover, it includes a suitable number of volunteers, and the observed associations showed high significance, which indicates the chance that the observations are true. This study can be used as a reference for future studies on EI in medical students and those on other courses in the health area. Some findings, such as the association between gender and age and the behavior of EI levels throughout the course need to be evaluated by further studies. Moreover, when considering EI as a skill, one must also evaluate the possibility of performing experimental studies that evaluate the effects of training of these skills on medical students.

\section{CONCLUSIONS}

The results of this study showed high EI levels in medical students. No association was observed between EI scores and the different years of the medical course. Age positively affected EI levels, while self-reported mental disorders had a negative effect on EI levels.

\section{REFERENCES}

1. Mayer JD, Roberts RD, Barsade SG. Human abilities: emotional intelligence. Annu Rev Psychol 2008;59:507-36.

2. Mayer JD, Caruso DR, Salovey P. The ability model of emotional intelligence: Principles and updates. Emotion Review 2016;8:290-300.

3. Birks YF, Watt IS. Emotional intelligence and patient-centred care. J R Soc Med 2007;100:368-74.

4. Canales R, Cleveland T. Emotional Intelligence: one Component in the HeART of Medicine. J Physician Assist Educ 2015;26:200-3.

5. Hernandez-Vargas CI, Dickinson-Bannack ME. Importancia de la inteligencia emocional en Medicina. Investigación en Educácion Médica 2014;3:155-60.

6. Johnson DR. Emotional intelligence as a crucial component to medical education. Int J Med Educ 2015;6:170-83.

7. Joseph N. Emotional intelligence and stress in medical students performing surgical tasks. Indian J Public Health 2016;60:166.

8. Toledo Júnior A, Duca JGM, Coury MIF. Tradução e Adaptação Transcultural da Versão Brasileira do Schutte Self-Report Emotional Intelligence Test. Rev Bras Educ Med 2018;42:109-14.

9. Schutte NS, Malouff JM, Hall LE, Haggerty DJ, Cooper JT, Golden CJ, et al. Development and validation of a measure of emotional intelligence. Pers Individ Dif 1998;25:167-77.

10. Fariselli L, Ghini M, Friedman J. White Paper: Age and Emotional Intelligence, Sixseconds. 2006. (Accessed 15/10/2019, 2019, at https:// prodimages.6seconds.org/media/WP_EQ_and_Age.pdf.)

11. Cabello R, Sorrel MA, Fernandez-Pinto I, Extremera N, FernandezBerrocal P. Age and gender differences in ability emotional intelligence in adults: A cross-sectional study. Dev Psychol 2016;52:1486-92.

12. Sharma D. Impact of Age on Emotional Intelligence and Its Components. International Journal of Research and Innovation in Social Science 2017;1:13-20.

13. Atkins PWB, Stough CK. Does Emotional Intelligence change with age? Society for Research in Adult Development Annual Conference. Atlanta, EUA2005.

14. Ciarrochi J, Hynes K, Crittenden N. Can men do better if they try harder: Sex and motivational effects on emotional awareness.
Cognition and Emotion 2005;19:133-41.

15. Kret ME, De Gelder B. A review on sex differences in processing emotional signals. Neuropsychologia 2012;50:1211-21.

16. McClure EB. A meta-analytic review of sex differences in facial expression processing and their development in infants, children, and adolescents. Psychol Bull 2000;126:424-53.

17. Carr SE. Emotional intelligence in medical students: does it correlate with selection measures? Med Educ 2009;43:1069-77.

18. Fernández-Berrocal P, Cabello R, Castillo R, Extremera N. Gender differences in emotional intelligence: The mediating effect of age. Behavioral Psychology 2012;20:77-89.

19. Joseph DL, Newman DA. Emotional intelligence: an integrative metaanalysis and cascading model. J Appl Psychol 2010;95:54-78.

20. Petrides KV, Furnham A. Gender Differences in Measured and SelfEstimated Trait Emotional Intelligence. Sex Roles 2000;42:449-61.

21. Miri MR, Kermani T, Khoshbakht H, Moodi M. The relationship between emotional intelligence and academic stress in students of medical sciences. J Educ Health Promot 2013;2:40.

22. Vasefi A, Dehghani M, Mirzaaghapoor M. Emotional intelligence of medical students of Shiraz University of Medical Sciences cross sectional study. Ann Med Surg (Lond) 2018;32:26-31.

23. Ciarrochi J, Deane FP, Anderson S. Emotional intelligence moderates the relationship between stress and mental health. Pers Individ Dif 2002;32:197-209.

24. Hansenne M, Bianchi J. Emotional intelligence and personality in major depression: trait versus state effects. Psychiatry Res 2009;166:63-8.

25. Hertel J, Schutz A, Lammers CH. Emotional intelligence and mental disorder. J Clin Psychol 2009;65:942-54.

26. Kosusha M, Bagheri HA, Heydarzadeh A. Emotional intelligence and anxiety, stress, and depression in Iranian resident physicians. Journal of Family Medicine and Primary Care 2018;7:420-4.

27. MANJU. Emotional Intelligence as Predictor of Mental Health among Chronic Disease Group. International Journal of Indian Psychology 2016;4:43-9.

28. Sodhi R. Emotional Intelligence as Predictor of Mental Health among Normal and Chronic Disease Group. International Journal of Indian Psychology 2016;4:129-40.

29. Rotenstein LS, Ramos MA, Torre M, Segal JB, Peluso MJ, Guille C, et al. Prevalence of Depression, Depressive Symptoms, and Suicidal Ideation Among Medical Students: A Systematic Review and MetaAnalysis. JAMA 2016;316:2214-36.

30. Pacheco JP, Giacomin HT, Tam WW, Ribeiro TB, Arab C, Bezerra IM, et al. Mental health problems among medical students in Brazil: a systematic review and meta-analysis. Braz J Psychiatry 2017;39:369-78.

31. Downey LA, Johnston PJ, Hansen K, Schembri R, Stough, C, Tuckwell V, et al. The relationship between emotional intelligence and depression in a clinical sample. European Journal of Psychiatry 2008;22:93-8.

32. Fernández-Berrocal P, Alcaide R, Extremera N, Pizarro D. The Role of Emotional Intelligence in Anxiety and Depression Among Adolescents. Individual Differences Research 2006;4:16-27.

33. Holt S, Jones S. Emotional intelligence and organizational performance: Implications for performance consultants and educators. Performance Improvement 2005;44:15-21.

7 REVISTA BRASILEIRA DE EDUCAÇÃO MÉDICA

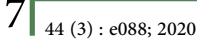


34. Khoshakhlagh $H$, Faramarzi $S$. The relationship of emotional intelligence and mental disorders with internet addiction in internet users university students. Addict Health 2012;4:133-41.

35. Brackett MA, Mayer JD. Convergent, discriminant, and incremental validity of competing measures of emotional intelligence. Pers Soc Psychol Bull 2003;29:1147-58.

36. Goldenberg I, Matheson K, Mantler JT. he Assessment of Emotional Intelligence: A Comparison of Performance-Based and Self-Report Methodologies. Journal of Personality Assessment 2006;86:33-45.

37. Hunsley J, Meyer GJ. The incremental validity of psychological testing and assessment: conceptual, methodological, and statistical issues. Psychological Assessment 2003;15:446-55.

38. Woyciekoski C, Hutz CS. Inteligência emocional: teoria, pesquisa, medidas, aplicações e controvérsias. Psicologia: Reflexão e Crítica 2009;22:1-11.

39. O’Connor RM, Little IS. Revising the Predictive Validity of Emotional Intelligence: Self-Report versus Ability-Based Measures. Pers Individ Dif 2003;35:1893-902.

40. Bastian VA, Burns NR, Nettelbeck T. Emotional intelligence predicts life skills, but not as well as personality and cognitive abilities. Pers Individ Dif 2005;39:1135-45.

41. Brown RF, Schutte NS. Direct and indirect relationships between emotional intelligence and subjective fatigue in university students. J Psychosom Res 2006;60:585-93.

42. Depape A-MR, Hakim-Larson J, Voelker S, Page S, Jackson DL. Self-talk and emotional intelligence in university students. Canadian Journal of Behavioural Science 2006;38:250-60.

43. Guastello DD, Guastello SJ. Androgyny, Gender Role Behavior, and Emotional Intelligence Among College Students and Their Parents. Sex Roles 2003;49:663-73.
44. Pau AK, Croucher R. Emotional Intelligence and Perceived Stress in Dental Undergraduates. J Dent Educ 2003;67:1023-8.

45. Saklofske DH, Austin EJ, Galloway J, Davidson K. Individual difference correlates of health-related behaviours: Preliminary evidence for links between emotional intelligence and coping. Personality and Individual Differences. Pers Individ Dif 2007;42:491-502.

46. Scott G, Ciarrochi J, Deane FP. Disadvantages of being an individualist in an individualistic culture: Idiocentrism, emotional competence, stress, and mental health. Australian Psychologist 2004;39:143-53.

47. Van Rooy DL, Alonso A, Viswesvaran C. Group differences in emotional intelligence scores: theoretical and practical implications. Pers Individ Dif 2003;38:689-700.

\section{AUTHORS' CONTRIBUTIONS}

Study conception and design (ATJ, MIFC and JGMD), data acquisition (MIFC and JGMD), data analysis and interpretation (ATJ, MIFC and JGMD), article drafting (ATJ and MIFC), critical article review for important intellectual content (ATJ, MIFC and JGMD) and final approval of the version to be published (ATJ, MIFC and JGMD).

\section{CONFLICTS OF INTEREST}

The authors declare no conflicts of interest.

\section{ADDRESS FOR CORRESPONDENCE}

Antonio Toledo Júnior. Rua Califórnia, 570/501, Belo Horizonte, MG, Brasil. CEP: 30315-500.

E-mail: antonio.toledo@unifenas.br 